\title{
AS DIFERENÇAS DE ADAPTAÇÃO FÍLMICA DE A FANTÁSTICA FÁBRICA DE CHOCOLATE
}

\author{
Gabriel Steindorff ${ }^{1}$ \\ Ana Cláudia Munari Domingos²
}

\begin{abstract}
Resumo: O presente artigo compara as diferenças de adaptação entre duas versões do filme $A$ fantástica fabrica de chocolate, a versão do diretor $\mathrm{Mel}$ Stuart (1971), e a versão do diretor Tim Burton (2005), ambas baseadas na obra literária do escritor Roald Dahl (1975). Para a análise utilizaremos o conceito de "perspectivas narrativas", das teorias de Reuter (2011), Genette (1972) e Tacca (1978), que colocam que a narrativa se estrutura através de determinado prisma, relacionado com o conceito de lacunas narrativas (ISER, 1999), que trata de vazios entre informações subentendidas e até incompletas ou não ditos. Este recurso estético serve para que o leitor complete com seu repertório e suas inferências. O objetivo do estudo é mostrar que a mesma obra pode ser adaptada de formas diferentes, a partir de distintas óticas, levando-se em consideração o tempo em que a história é narrada, por exemplo, ou a sensação que se deseja provocar no receptor.
\end{abstract}

Palavras-chave: Narrativa. Perspectiva. Personagem. História.

Abstract: This article compares the differences between the movies Willy Wonka and the Chocolate Factory, by Mel Stuart (1971) and Charlie and the Chocolate Factory by Tim Burton (2005), both based on the literary work by writer Roald Dahl (1975). The concept of "narrative perspective" developed by Reuter (2011), Genette (1972) and Tacca (1978) was used for analysis. It defines narrative as structured through certain prism, related to the concept of narrative gaps (ISER, 1999), which deals with gaps between implied, incomplete or even unsaid information. This aesthetic resource allows the reader completion with personal repertoire and its inferences. The objective is to show that the same work can be adapted in different ways, from different viewpoints, taking into account the time in which the story is told, for example, or the feeling one wishes to cause in the receiver

Keywords: Narrative. Perpective. Character. Story.

\section{INTRODUÇÃO}

\footnotetext{
${ }^{1}$ Bacharel em Comunicação Social - Radialismo/Produção em Mídia Audiovisual pela UNISC. Mestrando do Programa de Pós-Graduação em Letras da UNISC. Bolsista do Programa de Bolsas Institucionais para Programas de Pós-Graduação Stricto Sensu - BIPSS da UNISC.

2 Prof. ${ }^{a}$ Dr. ${ }^{\underline{a}}$ da disciplina Hiperleitura, Texto e Leitor do Programa de Pós-Graduação em Letras da UNISC.
} 
Quando se conta uma história, mesmo que informalmente, a alguém, dáse mais atenção a alguns detalhes e menos a outros. Essa seleção do que se vai ou não dizer é uma forma estética de criação, com o objetivo de causar determinado efeito ou sensação no receptor. Assim, quem conta uma história de suspense, por exemplo, não deve revelar o segredo dela antes do final ou eliminará toda a tensão e o entusiasmo do receptor, que utiliza as lacunas deixadas para completar e deduzir o final da história, como se narrador e receptor participassem de um jogo narrativo.

Assim como narrar é sempre selecionar elementos de uma história para causar determinado efeito - e assim o narrador é um leitor dessa história antes de ser seu criador, também a adaptação é uma leitura antes de uma criação, pois o autor da obra adaptada lê - interpreta, reorganiza, seleciona, recria, narra. O presente artigo compara as escolhas de perspectivas trabalhadas em duas versões cinematográficas da obra $A$ fantástica fábrica de chocolate, de Roald Dahl: a primeira versão, do diretor Mel Stuart (1971), que apresenta mudanças significativas em relação ao original de Dahl; e a segunda adaptação, de Tim Burton (2005), mais condicionada às perspectivas da história verbal, embora traga alguns elementos não constantes na obra original.

\section{A INDETERMINAÇÃO NA NARRATIVA}

Quando contamos uma história, independentemente da forma - escrita, oral, imagética, etc. - nos utilizamos da narração. Narração pode ser entendida como a contação da história, mas não só isso. Narração é algo mais amplo que um simples contar a história. Todas as decisões efetuadas no decorrer do "contar" fazem parte da narração: a linguagem e as palavras usadas, a disponibilização ou não de informações sobre as personagens, o espaço, os detalhes da fábula, a organização da sequência da história. Trata-se de toda a estruturação da história que será apresentada em forma de enredo:

De certo modo, o sentido específico em que aqui se fala de narração, relaciona-se com a ancestral concepção cultivada pela retórica; a narratio, como componente do dispositio (parte da técnica retórica que se ocupava da organização global do discurso e da sua 
economia interna - cf. Lausberg, 1982: 95-6), desempenha então uma função marcadamente ativa, de preparação da argumentação: "A narração, portanto, não é uma história (no sentido Fabuloso ou desinteressado do termo), mas uma prótese argumentativa". (Barthes, 1975a, 209 apud Reis; Lopes, 1988, p. 58)

A narração engloba, assim, vários elementos do contar a história, mas há de se ter ciência de que não existe apenas uma forma de narrar. Reuter (2011) explica como podem se apresentar os dois modos de narração: contar (diegese) e mostrar (mimese):

No primeiro modo, a mediação do narrador não é oculta. É visível. O narrador é aparente e não dissimula sua presença. [...] No segundo modo, o do mostrar, também chamado de mimese, a narração é menos aparente, para dar ao leitor a impressão de que a história se desenrola, sem distância, diante dos seus olhos, como se ele estivesse no teatro ou no cinema. (Reuter, 2011, p. 60)

Pode-se perceber, pela explicação do autor, que o modo de narração, denominado contar depende de uma entidade visível, ou seja, de um narrador claramente perceptível, enquanto no modo denominado mostrar essa entidade se apresente oculta. Note-se que no segundo modo o narrador não é inexistente, ele está lá, mas não aparece.

Segundo Reuter (2011), no modo mostrar, como o narrador tende a ocultar sua presença, ele basicamente terá "função de direção ou de controle (ele organiza a narrativa, na qual insere e alterna na narração, descrições e falas dos personagens)" (Reuter, 2011, p. 64). Em uma adaptação fílmica, cabe a esse narrador/diretor definir quais perspectivas serão mostradas na sua versão:

\begin{abstract}
A questão das perspectivas é de fato muito importante para a análise das narrativas, pois o leitor [espectador] percebe a história segundo um prisma, uma visão, uma consciência que determina a natureza e a quantidade das informações: podemos, com efeito, saber mais ou menos sobre o universo e os seres, podemos continuar fora dos seres ou penetrar sua interioridade. (Reuter, 2011, p. 73)
\end{abstract}

Ao se levar em consideração a perspectiva de um personagem para desenvolver a história, ficar-se-á atrelado ao seu ponto de vista, baseando a história nas experiências vividas pelo personagem, ou nas informações recebidas por ele. Por isso, é importante considerar quando se pensa em 
perspectivas narrativas, que é através deste conceito que se percebe quem está narrando a história, ou seja, através de qual personagem o espectador está percebendo os acontecimentos. Pouco antes de Reuter (2011), Genette (1972) classificou os três tipos de narradores a partir da quantidade de informações que tinham a respeito da história.

O primeiro tipo de narrador da tripartição (autodiegético, homodiegético e heterodiegético) proposta por Genette, o narrador autodiegético, é aquele que narra a sua própria história ocupando a posição central da narrativa. Ele se distingue do narrador homodiegético e do narrador heterodiegético devido à forma como estrutura a perspectiva narrativa, organiza o tempo e manipula a distância da narrativa. Este narrador efetivamente viveu a história que conta, sabe detalhes aprofundados e pode contar tudo sobre a experiência vivida. Para este tipo de narrador é bastante comum a narração em primeira pessoa.

Já o narrador homodiegético, para Genette é aquele que dispõe de informações de sua própria experiência no espaço diegético da história, entretanto se difere do narrador autodiegético pelo fato de não ser, além de narrador, o protagonista da história. Essa modalidade de narrador participa da narrativa de forma secundária, como um personagem muitas vezes próximo ao protagonista.

O narrador heterodiegético, ao contrário dos anteriores, não participa da narrativa, ele está alheio ao mundo diegético, ele não está na narrativa como personagem. Na maioria das vezes, portanto, sua narração é constituída em terceira pessoa, mas isso não impede que ele faça intrusões no texto em primeira pessoa.

Tacca (1978) entende a presença dos narradores de forma um pouco diferente do que Genette. Para Tacca, este "ponto de vista ou ângulo de enfoque, esta adoção de uma perspectiva determinada para ordenar o mundo assume, no romance, dois modos fundamentais:" (1978, p. 62) o narrador homodiegético e o narrador heterodiegético. Ao heterodiegético ele atribui as mesmas características que Genette atribuiu, entretanto, ao homodiegético, ele atribui a narração como participante da história, e trata a categoria autodiegética de Genette como uma forma na qual o narrador homodiegético 
pode atuar, ou seja, como uma função de um narrador que está dentro da história.

A diferença é muito sutil, mas Tacca (1978) avança, quando, ao relacionar a escolha do tipo de narrador com a perspectiva narrativa adotada, observa que desta forma o narrador, a partir da perspectiva narrativa, determina-se a quantidade de informação que o narrador tem da história que está narrando:

\begin{abstract}
Essa perspectiva tem sido caracterizada de diversos modos. Quanto a nós, deve traduzir sempre a relação entre narrador e personagem (ou personagens) do ponto de vista do 'conhecimento' ou 'informação'. Esta relação entre o conhecimento do narrador e o de seus personagens pode ser de três tipos: omnisciente (o narrador que possui um conhecimento maior do que o dos seus personagens), equisciente (o narrador possui uma soma de conhecimento igual à dos seus personagens); deficiente (o narrador possui menor informação que o seu personagem - ou personagens). (Tacca, 1978, p. 68)
\end{abstract}

Dessa forma, a escolha da perspectiva narrativa influenciará não só o conhecimento que o narrador possuirá da narrativa, mas também a sua autoridade para narrar. Assim, segundo Tacca (1978), enquanto o narrador heterodiegético, narrando em terceira pessoa, tende a se adaptar aos três tipos de perspectivas, ao narrador homodiegético, narrando em primeira pessoa, resta apenas a forma equisciente (saber equivalente ao dos personagens).

Dessa forma, as possibilidades da narrativa se restringem por um lado, mas se abrem pelo outro, ou seja, se em determinado filme o narrador conta a história por meio da perspectiva de um determinado personagem, deixando lacunas abertas a respeito de outros elementos da história; uma segunda adaptação da obra pode preencher as lacunas deixadas pela primeira, a fim de produzir outro efeito estético, propondo ao espectador essencialmente a mesma história do primeiro filme, mas com outro repertório - que advém, pois, de outra perspectiva. Mesmo assim, cada nova versão do filme ainda precisa deixar aspectos em aberto, permitindo que o espectador preencha as lacunas com sua experiência individual. Wolfgang Iser (1999) trata essas lacunas como o produto da indeterminação do texto, os vazios que permitem ao leitor preencher com seu próprio repertório e suas inferências: 
É fatal que se abram lacunas e que essas ofereçam um livre jogo de interpretação para o modo específico em que várias perspectivas podem ser conectadas umas às outras. Essas lacunas dão ao leitor a oportunidade de construir as suas próprias pontes, relacionando os diferentes aspectos do objeto que até aquele ponto lhe foi revelado. É impossível o próprio texto preencher as lacunas. [...] As seções indeterminadas ou lacunas dos textos literários não devem ser consideradas de forma alguma, como defeito: ao contrário, são um elemento básico para a resposta estética. (Iser, 1999, p.11)

Contudo, é importante lembrar que a afirmação de Iser sobre a existência de indeterminação no texto literário estende-se de forma geral a toda narrativa, independentemente da linguagem ou do gênero, em que ela se apresenta. Isso ocorre, segundo ele, porque o texto é construído (pela narração) de forma esquemática, como uma estrutura onde há espaço para o repertório do leitor. Assim, toda narrativa, sobretudo a ficcional, constrói-se sobre uma estrutura indeterminada, e esse nível de indeterminação é que pode ser controlado pelo narrador.

Certamente as narrativas não ficcionais tratam a inserção de lacunas de outra forma, visto que a presença da indeterminação em um texto histórico, por exemplo, não é ideal. A indeterminação é, conforme Iser (1999), uma prerrogativa tanto da ficção quanto da linguagem literária, presente também - e talvez, sobretudo - na poesia. As brechas deixadas pelo autor, através da voz do narrador, em nada tornam a narrativa menos atraente, pelo contrário, dão ao leitor maiores possibilidades de imaginar o que preenche essas brechas, além de possibilitar a abordagem da obra por outras perspectivas.

\section{NARRANDO A HISTÓRIA: O LIVRO}

A fantástica fábrica de chocolate é uma obra do escritor britânico Roald Dahl, cuja primeira edição surgiu em 1964, e conta a história de Charlie Bucket, um menino pobre que mora com seus pais e seus quatro avós em uma pequena e precária casa.

A família de Charlie muitas vezes não dispõe de alimentos para uma refeição digna e, quando tem o que comer, o único prato é geralmente uma 
sopa de repolho feita pela mãe do menino. O pai de Charlie é operário de uma fábrica de pasta de dentes, onde trabalha colocando as tampas nas bisnagas do produto.

$\mathrm{Na}$ cidade onde a família Bucket mora existe uma enorme fábrica de chocolate, do confeiteiro Willy Wonka. Wonka cria as mais maravilhosas receitas de balas, pirulitos, chocolates e doces em geral, despertando a inveja e a cobiça de seus concorrentes, que enviam espiões para sua fábrica. Após a ação de espiões, muito rapidamente, os concorrentes começam a produzir as receitas de Wonka, obrigando o confeiteiro a demitir todos os funcionários da fábrica e fechar as portas.

Charlie tem uma admiração muito grande pela fábrica e seu mistério, e sempre pergunta sobre ela para seus avós que lhe contam muitas histórias. Essas histórias, contadas na maioria das vezes pelo seu avô Joe, aumentam ainda mais a curiosidade do menino. Uma delas é a história do príncipe indiano que encomendou a Wonka um palácio de chocolate, onde tudo era de chocolate: os tijolos, o cimento que prendia os tijolos, os móveis, as obras de arte, etc. Willy Wonka, após entregar o palácio pronto, advertiu ao príncipe que começasse logo a comer, pois não ia durar muito. O príncipe disse que não pretendia comer o palácio, ele viveria nele. Então um dia extremamente quente, o palácio começou a derreter, transformando-se em uma enorme poça de chocolate líquido.

Eis que um dia as chaminés da fábrica começam novamente a largar fumaça, mas ninguém sabe quem está trabalhando lá. Os operários não entram nem saem, a única movimentação possível de se observar de fora da fábrica são os caminhões que saem de lá carregados de doces.

Com todo esse clima de mistério envolvendo a fábrica, Willy Wonka lança uma incrível promoção: ele coloca cinco convites dourados nas embalagens de chocolate que propiciam aos ganhadores conhecer sua fábrica. Esses cinco convites foram pra cinco lugares diferentes do mundo. Além da visita na fábrica, os ganhadores ainda receberiam um suprimento vitalício de doces e, por fim, uma das cinco crianças ganharia um prêmio especial.

A promoção de Wonka foi um sucesso, o mundo todo parou para correr atrás dos convites dourados, as crianças estavam enlouquecidas, inclusive Charlie, que ganhava somente uma barra de chocolate por ano, em seu 
aniversário, presente que ele cuidava como se fosse um tesouro. Guardando o chocolate com muito cuidado e comendo somente quando não aguentava mais de vontade, mesmo assim ele fazia a barra durar uns dois meses.

Sem muita demora, o primeiro bilhete dourado foi encontrado. Um garoto gordinho chamado Augustus Glope, que comia muito chocolate e tinha como passatempo justamente comer muito, foi o felizardo. Em seguida foi a vez de a mimada Veruca Salt exibir seu convite dourado. Filha de um industrial do ramo de nozes, seu pai parou todo o trabalho da fábrica para que os operários desembrulhassem milhares de barras de chocolate para achar 0 tal bilhete dourado.

Charlie e sua família, em especial o vovô Joe, acompanhavam a descoberta dos bilhetes dourados pelos jornais. No dia de seu aniversário, como de costume, Charlie ganhou sua barra de chocolate, mas essa tinha sido esperada com mais ansiedade, nutrida pela esperança de encontrar o convite dourado. Sob o olhar atento dos familiares, Charlie abre sua barra Wonka, mas nada encontra.

$\mathrm{Na}$ noite seguinte o pai de Charlie volta para casa com um jornal que traz a notícia de que mais dois bilhetes dourados foram encontrados, um por Violeta Beauregarde, a recordista de mascar chiclete, e um por Mike Tevê, um garoto viciado em televisão.

No dia seguinte, o Vovô Joe entrega a Charlie sua última moeda e pede que ele traga uma barra de chocolate com o objetivo de encontrarem o tão esperado bilhete dourado. Charlie pega o dinheiro e vai correndo à loja de doces comprar o chocolate para abrir com o seu avô, mas novamente não encontram o que procuram.

Pouco tempo depois a família começa a passar fome, a fábrica onde 0 pai de Charlie trabalhava teve que fechar e ele ficou sem seu emprego. Para conseguir comprar comida, o pai de Charlie trabalhava limpando a neve na casa das pessoas, o que só lhe rendia algumas moedas.

Certo dia, andando pela rua, Charlie encontra uma nota de um dólar, sua fome era tanta que ele decide ir à primeira loja de doces e comprar uma barra de chocolate, o restante do dinheiro decidiu dar para sua mãe. 
Charlie sentiu-se tão bem comendo aquela barra de chocolate que decidiu comer mais outra e, para sua surpresa, nesta segunda barra encontrou o tão sonhado bilhete dourado. Quando perceberam que o menino tinha encontrado o bilhete, os clientes da loja ficaram muito agitados, ofereceram a Charlie dinheiro e uma bicicleta nova em troca dele. O menino ficou assustado e foi salvo pelo dono da loja que falou para ele correr para casa e não entregar o bilhete a ninguém.

No dia da tão esperada visita à fábrica de chocolates, Charlie foi acompanhado do Vovô Joe, enquanto as outras crianças todas foram acompanhadas por seus pais e mães. A fabrica era maravilhosa, e Willy Wonka, um estranhíssimo anfitrião, com ideias malucas e produtos espantosos.

A primeira sala da fábrica a ser visitada foi a sala do chocolate, onde havia um rio e uma cachoeira de chocolate líquido que servia para bater o chocolate para ele ficar aerado. Segundo Wonka, somente dessa forma o chocolate obtinha sua textura perfeita. Nessa sala tudo era comestível, o anfitrião convidou as crianças e seus pais para comerem uma folha de grama que revestia o assoalho do ambiente, essa grama era feita de açúcar mentolado.

O rio de chocolate se tornou irresistível para Augustus Glope, que estava ajoelhado bebendo chocolate com as mãos, tanto que o menino caiu no rio e foi sugado por uma bomba que levava o chocolate líquido para um dos diversos setores da fábrica. Após Augustus ser sugado pelo tubo da bomba, apareceram os operários secretos da fábrica, os Umpa-Lumpas, que cantaram uma canção sobre o quanto Augustus era guloso e mal educado.

Os Umpa-Lumpas eram homenzinhos muito pequenos que vieram de uma tribo de pigmeus da floresta africana, lá só comiam lagartas verdes que tinham um sabor horrível, mas adoravam cacau. Então Wonka convidou-os para trabalhar na sua fábrica onde poderiam se alimentar somente de cacau e chocolates.

Após o acidente de Augustus Glope, as demais crianças continuaram o passeio pela fábrica, dessa vez navegando no rio de chocolate em um barco viking feito de açúcar-cande cor de rosa e movido por remos, que eram impulsionados por cem Umpa-Lumpas. Esse barco passava pelos mais 
diversos setores da fábrica, até que chegou numa sala da qual Willy Wonka tinha muito orgulho, a sala das invenções.

A sala das invenções era o lugar onde se encontravam todos os possíveis novos produtos da fábrica, produtos que ainda estavam sendo testados e desenvolvidos para irem com segurança para as lojas de doces do mundo. Lá estavam, por exemplo, a bala infinita que Wonka criou para crianças que recebem pouca mesada, ou seja, era necessário comprar apenas uma dessas balas, elas nunca acabavam nem diminuíam de tamanho. Também havia o caramelo cabeludo, que após ser comido fazia crescer novos tufos de cabelo e até barba.

$\mathrm{Na}$ sala das invenções também tinha a incrível máquina que fazia 0 chiclete refeição, uma guloseima que prometia acabar com todas as cozinhas do mundo. Quando Violeta Beauregarde viu a tira de chiclete saindo da máquina ficou muito empolgada e avançou retirando um pedaço e enfiando-o na boca mesmo após Willy Wonka falar que a invenção ainda não era segura.

Violeta se maravilhou com aquele doce, sentia a sopa de tomates descer por sua garganta, logo após a sopa, o chiclete lhe trouxe a sensação de estar comendo rosbife, bem macio e com molho, e por fim uma deliciosa torta de amoras. Quando chegou na torta de amoras, começou o problema a que Wonka se referia, o nariz da menina começou a ficar azul e ela começou a inchar. Sua mãe ficou assustada e perguntou a Wonka o que estava acontecendo, ele respondeu que havia avisado e que a menina estava virando amora. Novamente apareceram os Umpa-Lumpas para cantar uma canção sobre como é feio o hábito de uma pessoa passar o tempo todo mascando chiclete. Logo após a canção, os operários a levaram para a sala de sucos onde deveria ser espremida antes que explodisse.

Após 0 acidente de Violeta, as crianças restantes e seus acompanhantes seguiram o passeio com Wonka, passaram andando através de um corredor com diversas salas dos diferentes setores da fábrica. Passaram pela sala dos travesseiros comestíveis de marshmallows, pela sala dos papéis de parede com sabor e pela sala de sorvetes quentes para dias frios, até que chegaram à sala dos bombons que dão bola. Todos ficaram intrigados para saber o que eram esses bombons que dão bola. Veruca protestou, falou que se 
dão bola não são bombons, são chicletes. Wonka então tirou uma chave do bolso e mostrou ao que se referia. Ao abrir a porta, todos os bombons se viraram para a porta sorrindo e piscando para o grupo, o anfitrião então disse: "Viu, estão dando bola pra nós!"

Depois da sala dos bombons que dão bola chegou a hora de conhecer a sala das castanhas. Para espanto dos visitantes, não havia operários trabalhando lá, e sim esquilos, que selecionavam e retiravam as nozes que a fábrica utilizava em seus doces. Veruca Salti ficou muito impressionada com os esquilos e pediu pra seu pai comprar um daqueles esquilos treinados para ela, mas Wonka não quis vender nenhum. A menina ficou muito irritada e entrou na sala para pegar um esquilo, mesmo sem autorização. $O$ que ela não contava era que os esquilos iriam atacá-la, avaliá-la e descartá-la como as castanhas ruins. A mãe de Veruca ficou muito assustada e se aproximou do buraco no chão, que estava ligado ao duto de lixo para resgatar a menina, mas um dos esquilos a empurrou e a jogou no duto de lixo com a filha. $O$ pai de Veruca também correu para a boca do duto e foi derrubado para o lixo pelos esquilos. Depois que o pai de Veruca caiu, os Umpa-Lumpas retornaram pra cantar mais uma canção, dessa vez a respeito da teimosia da menina e como os pais haviam-na estragado ao mimá-la.

Mas ainda havia muita coisa para ser vista na fábrica e muito pouco tempo para o final da visita, então Wonka convidou Charlie, Mike e seus responsáveis para vencerem a distância em um elevador de vidro, que andava em todas as direções: para cima e para baixo, para esquerda e para a direita e até mesmo na diagonal. Esse elevador tinha um painel enorme, onde havia botões que levavam a todos os setores da fábrica. Mike perguntou a Wonka se não havia nenhum departamento de televisão, o anfitrião confirmou que havia e pra lá eles foram com o elevador.

A sala do departamento de televisão era toda pintada de branco, e a luz lá dentro era tão forte que exigiu que todos colocassem óculos especiais para não queimarem a retina. Mas a televisão que Wonka estava desenvolvendo não era uma televisão comum, com ela se poderia mandar uma barra de chocolate para a casa das pessoas, fazendo quem tivesse dúvida da qualidade do produto provar e comprovar. Mike ficou admirado quando Wonka mostrou que a televisão realmente fazia o que prometia, mas, para realmente funcionar, 
precisava de uma barra de chocolate gigante, que seria filmada e quando aparecesse no outro lado estaria em tamanho normal.

Mike quis saber se era possível de se enviar pessoas por esse aparelho, Wonka pensou um momento e disse que poderia, sim. O menino então saiu correndo, apertou um botão e se jogou na frente da câmera, mesmo com todos pedindo para que ele não fizesse tal coisa, e desapareceu diante dos olhos de todos, reaparecendo no aparelho de TV, do tamanho de um boneco pequeno.

Os pais de Mike ficaram assustados, como poderiam ter seu filho no tamanho normal novamente? Mas Wonka sugeriu que o colocassem numa máquina que testa até onde o chiclete pode esticar, assim Mike ficaria alto novamente, o único problema é que ele ficaria bem magro. Depois de levarem o menino para ser esticado, os Umpa-Lumpas apareceram de novo para cantar uma canção, dessa vez sobre os malefícios de se passar a vida toda diante da televisão.

Então, de todas as crianças convidadas, sobrou somente Charlie, e Wonka ficou muito animado por ser ele o menino que restava. Entraram novamente no elevador de vidro, Wonka apertou um botão e o elevador subiu velozmente até atravessar o teto da fábrica e ficar no ar como um helicóptero. Lá de cima, conseguiam ver as outras crianças saindo da fábrica, todas bem, e entrando nos caminhões carregados de chocolate que iriam levar pra casa. Mas para Charlie havia uma surpresa maior, ele havia ganhado de Wonka a sua fábrica de chocolate, onde poderia morar com toda a sua família.

\section{NARRANDO NO CINEMA: DUAS VERSÕES DA MESMA HISTÓRIA}

Este livro foi adaptado para o cinema em duas ocasiões, em 1971, pelo diretor Mel Stuart, e em 2005, pelo diretor Tim Burton. Em ambas, a essência da história é a mesma: um garoto pobre que depois de participar de uma promoção de uma marca de chocolates ganha a fábrica que promoveu o concurso. Os personagens são praticamente os mesmo e têm suas características e nomes preservados. A sequência de eventos, como, por exemplo, os episódios em que cada uma das crianças comete um erro e tem de abandonar o passeio, também permanece inalterada. 
Entretanto, de um filme para o outro existe a seleção de diferentes esquemas. O filme de Stuart mostra um Charlie órfão de pai, que tem que trabalhar e estudar, enquanto sua mãe trabalha lavando roupas. Já no livro, apesar da família de Charlie ser bastante grande, formada por seis adultos e o menino, o pai do menino é a única pessoa da família que trabalha:

O Sr. Baldi era a única pessoa da casa que tinha um emprego. Trabalhava numa fábrica de pasta de dentes, onde ficava o dia inteiro sentado num banco colocando tampas nos tubos cheios. Mas um tampador de tubos de dentifrício não ganha muito, e o pobre $\mathrm{Sr}$. Baldi, por mais que trabalhasse, por mais rápido que tampasse os tubos, nunca conseguia ganhar dinheiro suficiente para comprar metade das coisas que uma família tão grande precisava. (Dahl, 1975 , p. 16)

Outra diferença é que a obra de Stuart faz algumas alterações na história original, ou a estende, trazendo elementos que não estão no livro. Por exemplo, no livro há um episódio em que esquilos treinados selecionam castanhas, reservam as boas para os chocolates e descartam as ruins. No filme de Stuart, esse evento compõe outra cena, em vez de esquilos seletores existem patas que colocam ovos de chocolate envolvidos por papel dourado, e em vez de os esquilos avaliarem Veruca Salti, ela senta em uma balança com alçapão, onde os ovos são avaliados e, se não estão bons, caem pelo alçapão, e a menina é descartada por ali.

Ao comparar o episódio do descarte de Veruca, percebe-se que os elementos do filme de Burton correspondem mais aos do livro, pois utiliza elementos muito semelhantes aos descritos por Dahl, ou seja, no filme, o diretor reproduziu detalhes encontrados na narrativa literária. $O$ cenário é uma sala grande em forma de círculo onde os esquilos trabalham avaliando as nozes. Quando encontram uma que não está adequada aos padrões, jogam-na para trás para que caia no duto que se encontra no meio da sala. Assim como na obra de Dahl, Veruca tenta pegar um esquilo, mas é atacada, avaliada e descartada no duto como uma noz ruim:

No momento em que ela entrou na sala, cem esquilos pararam o que estavam fazendo e voltaram a cabeça para olhar para ela com seus olhinhos de contas negras. 
Veruca parou também olhando para eles. Seu olhar caiu sobre um esquilo pequenininho, sentado perto dela. Ele segurava uma castanha nas mãos.

- Vou ficar com este aqui! - disse ela.

Estendeu as mãos para agarrar o esquilo, mas quando fez isso... no momento exato em que suas mãos começaram a se mover, houve um movimento súbito na sala, como um clarão marrom, e todos os esquilos da sala voaram em direção a ela, jogando-a no chão.

Vinte e cinco esquilos agarraram seu braço direito, prendendo-o no chão.

Vinte e cinco esquilos agarraram seu braço esquerdo, prendendo-o no chão.

Vinte e cinco esquilos agarraram sua perna direita, prendendo-o no chão.

Vinte e quatro esquilos agarraram sua perna esquerda.

E o esquilo restante - obviamente o líder - subiu para seu ombro e começou a bater em sua cabeça com os nós dos dedos: tap-tap-tap... - Salvem minha filha! - gritava a Sra. Salti. - Veruca, volte! O que estão fazendo com ela?

- Estão testando para ver se ela está boa ou não - respondeu Sr. Wonka.

Veruca lutava furiosamente, mas os esquilos não a deixavam fazer o menor movimento. O esquilo líder continuou batendo em sua cabeça. E de repente os esquilos começaram a arrastá-la pelo chão.

[...]

- Para onde vão leva-la? - perguntou aflita a Sra. Salti.

- Ela vai para onde vão todos os frutos que não prestam - respondeu o Sr. Wonka. - Vai para o lixo. (Dahl, 1975, p. 143-144)

Entretanto, mesmo esse episódio apresenta novos esquemas. Há uma diferença quanto aos acompanhantes da menina. Enquanto, no livro, a mãe tem um papel bastante destacado na cena da sala de castanhas, inclusive tentando resgatar a menina do duto de lixo, antes mesmo do pai, no filme a mãe não está presente na visita à fabrica, Veruca é acompanhada somente pelo pai. Mesmo assim o desfecho do evento é o mesmo, o pai tenta alcançar a filha dentro do duto de lixo, mas também é empurrado por um esquilo.

O filme de Stuart também mostrava outros dois eventos que não constam no livro: Vovô Joe e Charlie bebendo um pouco da bebida volátil de Wonka, que fazia as pessoas flutuarem; e o vilão Slugworth, que tentava roubar a fórmula da balinha infinita de Wonka. Esses dois episódios que foram incorporados à história tiveram uma grande influência sobre o final desta versão, já que Charlie estava prestes a perder a fábrica por ter provado, sem a autorização de Wonka, a bebida volátil. O que salva o menino de perder a fábrica é devolver a balinha infinita a Wonka. Admirado com a atitude do garoto, Wonka então revela que Slugworth na verdade é seu funcionário 
Wilkinson, que tinha como tarefa testar a integridade das crianças. Em seguida, Wonka comunica a Charlie que ele será seu herdeiro.

Através da comparação desses dois eventos entre o livro e a adaptação de Stuart, podemos dizer que a adaptação de Tim Burton guarda mais semelhanças com a obra original - busca, assim, resolver a indeterminação em vez de inserir novos esquemas ou modificar o já dado. O filme preenche algumas lacunas deixadas pela versão de Stuart, como, por exemplo, a figura do pai de Charlie, que está presente no livro e foi omitida na versão de Stuart, as histórias paralelas que o Vovô Joe contava, a excursão de Willy Wonka à Lumpalândia em busca de sabores exóticos para seu chocolate, que termina com a descoberta de seus operários, os Umpa-Lumpas. Neste caso, fica bem claro como é esse processo de preencher as lacunas: o diretor busca responder à pergunta do leitor: de onde vieram os Umpa-lumpas?

A sequência do filme de Burton obedece a do livro, com 0 encadeamento das cenas e situações quase na mesma ordem, primando por uma leitura que se aproxima da obra original em livro. No entanto, também houve reformulação, principalmente na criação de uma história paralela para a vida de Willy Wonka, mostrando sua infância e sua relação com seu pai, Wilbur Wonka, um dentista que odiava doces e impedia que Willy os consumisse. Neste caso, também podemos dizer que Burton, como leitor, responde à pergunta sobre a ausência do pai de Wonka, tentando justificar o comportamento do filho a partir do pai. Assim, o menino, impedido pelo pai dentista de comer doces resolve ter sua própria fábrica. É esse tipo de vazio de não dito - que possibilita a que os adaptadores construam novos esquemas sem, no entanto, alterar o já dado ou corromper o enredo da história original.

Nesta versão, assim como no livro, não existe a figura de Slugworth, nem a situação de Charlie e o avô tomando a bebida volátil. Mesmo assim o menino corre o risco de perder a posição de herdeiro de Wonka, por não querer deixar sua família para morar na fábrica com o confeiteiro. A situação só é resolvida quando Charlie convence Wonka a resolver os problemas com seu pai. Eles vão até a casa de Wilbur e descobrem que o pai de Willy era um grande admirador do trabalho do filho, com vários recortes de jornais espalhados pelas paredes do consultório, onde se poderiam ler notícias sobre Willy. 
O episódio da casa de Wilbur Wonka também revela a perspectiva narrativa do filme. Podemos perceber que o narrador da história está bem próximo de Willy, conduzindo a visão e as expectativas do espectador. A partir do momento que descobre a existência do pai de Willy Wonka, através de flashbacks do personagem, a indeterminação do texto constrói no espectador uma imagem de um pai rígido e possivelmente envergonhado pelo que o filho se tornou. O espectador só descobre a admiração do pai, no mesmo momento que Willy. Isto mostra que o narrador estava dentro da história, perto de Willy Wonka, mas tinha tanta informação sobre Wilbur quanto os demais personagens.

Já na obra de Stuart vemos o enfoque mais próximo a Charlie, quando bem no início do filme percebemos o personagem espiando outras crianças na loja de doces. Na cena seguinte, quando vai entregar jornais, passa diante da fábrica de chocolate fechada e espia pelas grades. Neste momento o espectador tem a sensação da admiração do garoto pela fábrica e seus mistérios, como se estivesse ao lado do personagem.

Outro fator que é facilmente observado é o título da obra. O título brasileiro das três obras é o mesmo, A fantástica fábrica de chocolate, mas o título das obras em inglês muda de uma para outra. Na obra de Dahl, a perspectiva está no personagem Charlie, e o título original da obra é Charlie and the chocolate factory. Já a primeira adaptação para o cinema, de Stuart, traz o título no idioma original como Willy Wonka and the chocolate factory, mas, apesar do título, a perspectiva se mantém em Charlie, pouco se sabe a repeito de Wonka. Já no filme de Burton, o título no idioma original novamente é Charlie and the chocolate factory, no entanto, a perspectiva aponta para Wonka.

A alteração do título da obra de Stuart pode ter sido motivada pelos novos esquemas inseridos, que não poderiam ser justificados pela obra literária, como o episódio de Sloghworth e o episódio da bebida volátil, que influenciaram diretamente o desfecho do filme. Já a utilização do título original da obra de Dahl, por Burton pode ser entendido como um compromisso de esquematização narrativa similar à obra literária, trazendo novos elementos 
apenas através da mudança de perspectiva e não de novas situações na narrativa principal.

Pode-se também observar nas capas dos DVDs utilizados para este estudo que, apesar de o titulo da obra destacar um dos personagens, a ilustração destacava outro, dando enfoque à perspectiva narrativa, ou seja, em Willy Wonka and the chocolate factory, quem aparece em destaque na ilustração é o personagem Charlie, e isto se justifica por percebermos a perspectiva narrativa próxima a ele. Já em Charlie and the chocolate factory, a ilustração destaca o personagem Willy Wonka e nota-se que a perspectiva do filme está próxima a ele.

\section{CONCLUSÃO}

Pode-se identificar, em ambas as versões fílmicas da obra, diferentes escolhas interpretativas que, quando selecionadas, desencadearam a criação de situações que as justificassem. Assim como a cena da bebida volátil, no filme de Stuart, justifica-se no desfecho do filme para criar a tensão do menino não receber o prêmio, mesmo sendo a última criança que restou do passeio. Nesta versão, a moral concentra-se no caráter de Charlie, que mesmo após perder o grande prêmio que seria a fábrica de chocolate, consegue recuperá-la por devolver a balinha infinita a Wonka em vez de entregar ao suposto concorrente Slogworth, mostrando assim a honestidade do menino. No filme de Burton, a perda da fábrica por Charlie não querer deixar sua família justifica-se pela relação familiar de Wonka na infância, resolvida, assim, em paralelo com a situação de Wonka e seu pai. Essa versão parece ser um pouco mais moralizante, por assim dizer, já que Charlie acaba ajudando Wonka tanto quanto ele o ajuda, e o final mostra a importância da família para ambos.

Assim, as lacunas a respeito da família de Wonka deixadas pelo livro foram em parte preenchidas pelo filme de Burton, e as histórias paralelas sobre o personagem trouxeram ao espectador novas informações, o que tornou o filme atraente tanto para os espectadores que conheciam a história quanto para aqueles que ainda não estavam familiarizados com ela. 
Assim, pode-se notar que a perspectiva narrativa do primeiro filme se concentra próxima de Charlie, existindo nessa obra um narrador homodiegético oculto que está próximo ao garoto. Já no filme de Burton, percebe-se esse narrador junto a Willy Wonka e equiciente, ou seja, com a mesma quantidade de informações que os personagens.

Ao analisar os títulos das obras em seu idioma original, notou-se que houve mudanças esquemáticas na obra de Stuart, e por isso se justifica a mudança do título para Willy Wonka and the chocolate factory. Já no filme Burton os esquemas narrativos estão mais semelhantes ao livro de Dahl, o que se justifica para atribuir o título original da obra para esta adaptação.

Em contraste com os títulos dos filmes em idioma original, percebe-se nas capas dos DVDs utilizados para esta pesquisa que os personagens com maior destaque nas ilustrações são aqueles nos quais se prende a perspectiva narrativa, Na obra de Stuart, em que a perspectiva está próxima a Charlie, este personagem se destaca na capa do filme. Na obra de Burton, em que o narrador está próximo de Willy Wonka, este personagem é quem se destaca na capa do filme.

Percebe-se, portanto, que mesmo sendo a obra de Dahl um clássico da literatura infantil vastamente lido e cuja história é bem conhecida, também, através da versão de Stuart, existem lacunas capazes de serem preenchidas pelos leitores da obra que podem concretizar versões diferentes a partir da resolução da indeterminação. Também é possível notar que ao adaptar uma obra literária pode-se optar por seguir o caminho trilhado pela narrativa original ou adotar a perspectiva de determinado personagem. Desta forma muda-se 0 foco narrativo e exploram-se novos elementos da história.

\section{REFERÊNCIAS}

A FANTÁSTICA fábrica de chocolate. Direção de Mel Stuart. Produção Warner Bros; 1971. 100min, son, color.

A FANTÁSTICA fábrica de chocolate. Direção de Tim Burton. Produção Warner Bros; 2005. 106min, son, color.

DAHL, Roald. A fantástica fábrica de chocolate. Rio de Janeiro: Tecnoprint, 1975. 
GENETTE, Gérard. Figuras III. Barcelona: Lumen, 1972.

ISER, Wolfgang. A indeterminação e a resposta do leitor na prosa de ficção. Porto Alegre: PUCRS, 1999.

REIS, Carlos; LOPES, Ana Cristina M. Dicionário de teoria da narrativa. São Paulo: Ática, 1988.

REUTER, Yves. A análise da narrativa. 3. ed. Rio de Janeiro: DIFEL, 2011.

TACCA, Oscar. As vozes do romance. Coimbra: Almedina, 1983. 